\title{
THE SYSTEM OF TRADE BETWEEN JAPAN AND THE EAST EUROPEAN COUNTRIES, INCLUDING THE SOVIET UNION
}

\author{
Yataro Terada*
}

\section{INTRODUCTION}

Poor in natural resources, Japan has long been dependent on overseas supply for most of her raw material and fuel requirements. While imports of raw materials and fuel by the United States and West Germany in 1970 accounted respectively for I4 per cent and 22 per cent of their total imports, Japan's imports of raw materials and fuel in the same year amounted to about 59 per cent of her total imports. In addition, Japan depends on imports from foreign countries for 100 per cent of her wool, raw cotton, and nickel; 98 per cent of her petroleum; 95 per cent of her iron ores; and 55 per cent of her industrial coal. Such being the case, one of the guiding principles in Japan's foreign trade policy has been to expand trade with any country, regardless of its political system.

Japan was plagued by a gap between her economic growth and her international balance of payments until the mid-196o's and, in order to improve this situation, promotion of exports was given highest priority. Thus, efforts have been made to expand trade with the Soviet Union and East European countries on a commercial basis.

After the resumption of private foreign trade in 1949, trade between Japan and the Soviet Union and East European countries was conducted at a low level for some time. However, since the conclusion of a treaty of commerce and an agreement on trade and payment with the Soviet Union in 1957, and the conclusion of treaties of commerce with Poland and Czechoslovakia in 1958 and 1959 , Japan's trade with Eastern Europe has increased yearly. In 1970, the total of Japanese trade with this area broke the $\$ \mathrm{I}$ billion mark ( $\$ 822$ million in trade with the Soviet Union, and $\$ 218$ million in trade with East European countries). However, these figures account for only 2.2 per cent and 0.6 per cent respectively of Japan's total world trade in r970. Compared to the figures for Japanese trade with the United Kingdom and West Germany- $\$ \mathrm{r} .5$ billion and $\$ 3.6$ billion respectively-they are still at a relatively low level.

As can be seen from Table I, Japan's imports from the Soviet Union have continued to exceed its exports to that country. However, while exports from Japan to the Soviet Union have expanded steadily in recent years, imports to Japan from the Soviet Union have shown little increase. The primary reason for such a trend can be explained by the fact that while machinery, plants, steel products, and plastic and

\footnotetext{
- Ministry of International Trade and Industry, Japan.
} 
consumer goods have steadily been exported from Japan in response to Soviet demands generated by the implementation of the project for developing Siberia (Project for the Development of the Forest Resources in the Far East), a recession in Japan, and an increased internal demand for energy together with a shortage of transportation facilities in the Soviet Union have caused the reduction of imports from the latter.

TABLE I

JAPANese-Soviet Trade

\begin{tabular}{|c|c|c|c|c|c|c|c|c|}
\hline \multirow[b]{2}{*}{ Year } & \multirow[b]{2}{*}{$\begin{array}{l}\text { Export } \\
\text { (in millions } \\
\text { of dollars) }\end{array}$} & \multirow[b]{2}{*}{$\begin{array}{l}\text { Import } \\
\text { (in millions } \\
\text { of dollars) }\end{array}$} & \multicolumn{2}{|c|}{$\begin{array}{l}\text { Share in the } \\
\text { Total World } \\
\text { Trade of Japan } \\
\text { (\%) }\end{array}$} & \multicolumn{2}{|c|}{$\begin{array}{c}\text { Share in the } \\
\text { Total World } \\
\text { Trade of the } \\
\text { Soviet Union (\%) }\end{array}$} & \multicolumn{2}{|c|}{$\begin{array}{l}\text { Share in the } \\
\text { East-West Trade } \\
\text { of the } \\
\text { Soviet Union (\%) }\end{array}$} \\
\hline & & & Export & Import & $\begin{array}{l}\text { Import } \\
\text { from } \\
\text { Japan }\end{array}$ & $\begin{array}{c}\text { Export } \\
\text { to } \\
\text { Japan }\end{array}$ & $\begin{array}{l}\text { Import } \\
\text { from } \\
\text { Japan }\end{array}$ & $\begin{array}{c}\text { Export } \\
\text { to } \\
\text { Japan }\end{array}$ \\
\hline $\begin{array}{l}1967 \\
1968 \\
1969 \\
1970 \\
1971\end{array}$ & $\begin{array}{l}158 \\
179 \\
268 \\
341 \\
377\end{array}$ & $\begin{array}{l}454 \\
464 \\
461 \\
481 \\
496\end{array}$ & $\begin{array}{l}1.5 \\
1.3 \\
1.6 \\
1.8 \\
1.6\end{array}$ & $\begin{array}{l}4.5 \\
3.5 \\
2.9 \\
2.5 \\
2.5\end{array}$ & $\begin{array}{l}1.9 \\
2.0 \\
2.6 \\
2.9 \\
-\end{array}$ & $\begin{array}{l}3.7 \\
3.7 \\
3.0 \\
3.0 \\
-\end{array}$ & $\begin{array}{l}6.4 \\
6.1 \\
7.3 \\
8.4 \\
-\end{array}$ & $\begin{array}{r}10.8 \\
11.2 \\
0.0 \\
8.0 \\
-\end{array}$ \\
\hline
\end{tabular}

TABLE II

Japan's Trade with Eastern Europe

(EXcLUDING THE SoVIET UNION)

\begin{tabular}{|c|c|c|c|c|}
\hline \multirow[b]{2}{*}{ Year } & \multirow{2}{*}{$\begin{array}{l}\text { Export } \\
\text { (in millions } \\
\text { of dollars) }\end{array}$} & \multirow{2}{*}{$\begin{array}{l}\text { Import } \\
\text { (in millions } \\
\text { of dollars) }\end{array}$} & \multicolumn{2}{|c|}{$\begin{array}{l}\text { Share in the Total World } \\
\text { Trade of Japan (\%) }\end{array}$} \\
\hline & & & Export & Import \\
\hline 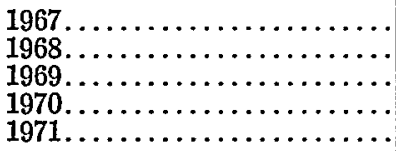 & $\begin{array}{r}71 \\
54 \\
74 \\
107 \\
159\end{array}$ & $\begin{array}{r}108 \\
109 \\
113 \\
111 \\
83\end{array}$ & $\begin{array}{l}0.7 \\
0.4 \\
0.5 \\
0.6 \\
0.7\end{array}$ & $\begin{array}{l}0.9 \\
0.8 \\
0.8 \\
0.6 \\
0.4\end{array}$ \\
\hline
\end{tabular}

While exports from Japan to the Soviet Union are likely to show a steady increase for the future, those factors restraining imports from the Soviet Union will not be overcome for some time, and Soviet imports are expected to continue to be sluggish. As a result, the past trend in Japanese-Soviet trade relations, that is, an excess of imports over exports on the Japanese side, is expected to further improve so far as Japan is concerned.

On the whole, Japan's trade with East European countries has expanded smoothly (Table II). In I971, exports and imports combined totaled \$242 million, showing an increase of II per cent over the previous year. However, while the export portion of the total trade increased remarkably by 48.6 per cent, to $\$ 159$ millon, the import portion declined by $\$ 83$ million, or 74.8 per cent of the figure for 1970 . The favorable trend in exports was due primarily to the increase in the export of steel and 
machinery. Increases were particularly noticeable in exports to Poland, Rumania, and East Germany. On the other hand, imports from East European countries have weakened somewhat since $x 968$, owing primarily to the decrease in the import of crude oil from Rumania, and of pig iron from Poland and East Germany.

East Europe is geographically remote from Japan. For this reason, imports from East European countries are limited to such items as agricultural products, mineral fuel, and machinery. Moreover, these countries are lacking in foreign currency. All of these factors are responsible for trade between Japan and East European countries having failed to attain a satisfactory level.

\section{I}

\section{Formal Trade Arrangements}

\section{A. Most-Favored-Nation Treatment}

In I957, immediately after the resumption of diplomatic relations with the socialist states of East Europe, Japan concluded a treaty of commerce with the Soviet Union. With this as a start, Japan proceeded to conclude treaties of commerce with Poland and Czechoslovakia in 1958 and 1959 , and with Rumania and Bulgaria in 1969 and I970. At present, Hungary is the only East European country with which Japan has diplomatic relations and yet has not concluded a treaty of commerce.

The primary characteristics of these treaties of commerce are almost identical. They provide for mutual most-favored-nation treatment with regard to customs duties, other export and import charges, internal taxes, and matters related to shipping, including departure and entry of merchant vessels. This is in contrast to EastWest relations generally. Western countries, even when they give either de jure or de facto MFN treatment to East European countries with regard to customs duties and other matters, do not include the products of these countries in their import liberalization measures, thus discriminating against imports from these countries. The Western countries make such discriminations lest the East European countries export their goods at low prices fixed in disregard of production costs, and thus disturb markets in the West. It is said, furthermore, that the Western countries maintain such discriminatory measures as bargaining instruments for future negotiations with Eastern Europe. Japan, however, has taken no discriminatory measures against these countries, which, though it may sound paradoxical, has strengthened Japan's bargaining position. Japan has often emphasized this independent attitude in various talks with both the East and the West.

\section{B. Scheme of Tariff Preferences}

The Japanese scheme of tariff preferences for developing countries came into effect in October, I97I, after necessary legislative measures had been taken in accordance with the United Nations General Assembly resolution adopted in October, 1970. Yugloslavia, Bulgaria, and Rumania-among East European countries-having 
expressed a desire to become beneficiaries of the preferential tariff scheme, the government of Japan decided to apply these rates to Yugoslavia beginning in August, I97r, and to the latter two as of April, 1972, by designating them beneficiaries of the scheme.

\section{Trade Agreement}

Upon concluding treaties of commerce with East European states, Japan also concluded trade agreements with many of them. However, no trade agreement has yet been concluded with Czechoslovakia, and, while no treaty of commerce has been concluded with Hungary, there is a trade agreement with that country. These agreements consist of the text, with a list of export and import items attached to it, and the exchange of notes.

The trade agreements generally provide that both governments will endeavor to facilitate issuance of licenses for export and import transactions; that such licenses will be issued in accordance with laws and regulations in force or to be put into force in the respective countries; that the settlement will be made in a convertible currency; that recourse to an arbitration agency in both countries will be encouraged for settling a dispute; that a meeting will be held to review the implementation of the agreement; and so forth.

Among the countries of Eastern Europe, it is the Soviet Union that has most consistently attached importance to the trade agreement. Other East European countries have, on the whole, paid little attention to the operation of such agreements. Consequently, bilateral trade agreements between Japan and East European countries are of almost no practical significance. However, between Japan and the Soviet Union meetings have been held every year in accordance with the provisions of the agreement. The representatives have held consultations on such agenda items as review of the trade performance during the previous year, prospects for export and import during the current year, matters requiring improvement concerning transactions, the question of a compulsory export-import package, and the question of the offices of Japanese trade companies in Moscow.

Both the Japanese government and the country's private businessmen have considered the conventional trade agreement useful for several reasons, some of which include the following:

(I) Yearly consultation on a governmental basis is more effective than negotiation by Japanese private organizations with the government of the Soviet Union as a means of solving the various problems which hamper expansion of Japanese-Soviet trade.

(2) It is possible, through such an inter-governmental meeting, to obtain official information from the government of the Soviet Union relating to the production, as well as to the supply and demand, situation of principal commodities in the Soviet Union, the trade and economic relations between the Soviet Union and other countries, and possible changes in such relations. 
(3) While the quantity of each commodity listed on the table of export and import items is merely an estimate as far as the Japanese side is concerned, it serves as an indicator for the planning agencies, ministries, industrial units, commercial organs, and trade corporations of the Soviet Union in their activities concerning trade with Japan, such as formulating a program, securing a portion of the budget, and allocating a quota of materials. Therefore, such estimate figures for the quantity of export and import commodities can also serve as guidelines for the activities of Japanese private industries, including investment, production, and marketing. In particular, since those figures show the amount of commodities which the Japanese side can legitimately require the Soviet Union to import, they are in a sense a useful means of promoting Japan's exports.

(4) Such an agreement makes it possible for the Japanese side to obtain longterm prospects for the availability of raw materials and fuel from the Soviet Union.

(5) Should the Soviet Union export commodities to Japan at such low prices as to threaten to disturb the Japanese market, the agreement will provide for protection of the Japanese side through direct negotiation with the government of the Soviet Union.

\section{Trade Planning}

The prospect for export and import trade announced by the government of Japan is worked out every year by the working group subordinate to the Trade Council. The latter is composed of the Prime Minister as chairman, ministers, and members of the Diet (Law Establishing the Prime Minister's Office of I949). Its purpose is to investigate and to discuss trade policies, export targets, and other important trade problems which require communication and coordination among the administrative organs concerned. Under the Council, there are industry-wide subcommittees dealing respectively with iron and steel, machinery, chemicals, textiles, and others, which number fourteen in all. These subcommittees formulate the industry-wide and market-wide targets for both exports and imports and refer them to the Council for its approval. These targets, which are also formulated country-wide with regard to Eastern European countries, are merely the objectives that Japan endeavors to reach, and are not of a rigid or binding nature. In addition, amounts of exports and imports during the period of the agreement are estimated in accordance with the trade agreement between Japan and the Soviet Union.

Until I970, a table of export and import items was attached to the Japan-Soviet Union trade agreement, and to each item were appended figures for the quantity or value which was expected to be reached each year. However, under the present agreement, covering the period from I97I to I975, the listing of such estimate figures is dispensed with, although a table of items is still attached. This change was primarily for practical reasons. That is, despite the fact that the actual performance of 
Japanese-Soviet trade has shown a constant excess of imports over exports on the Japanese side, an attempt was made, when both governments were working out estimate figures, to maintain export-import balances or to modify the actual imbalance on the list of items, notwithstanding the structural nature of the imbalance. This led to a frequent discrepancy between the estimates and the actual performance. Therefore, the utility of such an estimation has recently come to be questioned.

Nevertheless, export and import estimates have been worked out during the course of consultation between the two governments, even under the present agreement. According to the estimates, the total of exports and imports during the fiveyear period will amount to approximately $\$ 5.2$ billion (on the basis of the former exchange rate), and the average annual growth rates of Japan's exports and imports are 15.9 per cent and 9.6 per cent respectively. These estimates were not arrived at through an agreement between Japan and the Soviet Union, but were made by the Japanese side alone. (It would have required a prolonged negotiation to come to an agreement on concrete figures between the two countries, and such a negotiation was not undertaken!)

TABLE III

The New Japanese-Soviet Five Year Agreement (1971-75) Estimated EXPORT AND IMPORT (FOB basIs)

\begin{tabular}{l|r|r|r|r|r|r|r}
\hline \hline & 1971 & 1972 & 1973 & 1974 & 1975 & Total & $\begin{array}{c}\text { Average Annual } \\
\text { Growth Rate }\end{array}$ \\
\hline $\begin{array}{c}\text { Export from Japan (in } \\
\text { millions of dollars)......... }\end{array}$ & 379 & 424 & 571 & 610 & 683 & 2,667 & $15.9 \%$ \\
$\begin{array}{c}\text { Import into Japan (in } \\
\text { millions of dollars)......... }\end{array}$ & 412 & 462 & 488 & 538 & 594 & 2,494 & \multicolumn{1}{c|}{$0.6 \%$} \\
\hline Total.................. & 791 & 886 & 1,059 & 1,148 & 1,277 & 5,161 & $12.7 \%$ \\
\hline
\end{tabular}

II

Trade Agencies; Conclusion of a Contract;

Organizations for Trade Promotion

\section{A. Trade Agencies}

Most of the Japanese traders who conclude export or import contracts with the East European trade organizations are the so-called sogo shosha or all-around trade firms, fourteen or fifteen in number, the very existence of which appears to be peculiar to Japan. In addition to these trading companies, there are enterprises of a cooperative form which take part in the Japanese-East European trade. Their existence and participation is explained by the fact that the countries of Eastern Europe have trade organizations belonging to consumers' cooperatives, and these organizations have given priority to trade with foreign cooperatives. Trade between cooperatives has a special character in Japanese-Soviet trade in that it has a feature 
of a regional trade, similar to coastal trade in which consumer goods are the primary items in which the Japanese cities along the coast of the Sea of Japan are particularly interested.

All-around trading companies did not come onto the East-West trade scene until the late I960's. Until that time, each all-around trading company had set up a dummy company under the same personnel and capital, and through this dummy the company engaged indirectly in East-West trade. The change that took place is due largely to the efforts of Mr. Mikoyan, former President of the Presidium of the Supreme Soviet, who visited Japan in I964. Mr. Mikoyan's visit to Japan was part of the new (Ig66-70) Five Year Economic Plan of the Soviet Government. Under this plan, it sent high government officials to advanced countries to hold talks designed to promote economic cooperation.

When Mr. Mikoyan arrived in Japan, he presented to the Japanese government a list of orders for various chemical industries amounting to $\$ 35^{\circ}$ million. At the same time, he explained the Project for the Development of Siberia, and attempted to secure Japanese investment in the project. He met not only with leaders of Japanese economic circles through such organizations as the Japan Chamber of Commerce and Industry, and the Federation of Economic Organizations, but he also held talks with former zaibatsu groups of Mitsui, Mitsubishi, and Sumitomo, and he succeeded in dispelling the pro-American and anti-Soviet bias which had influenced these leaders of Japan's economy by persuading them of the great potential of the Soviet market.

Soon after the talks had been completed, the Sumitomo group announced that it would stop using a dummy, and that each company in the group would start doing business directly with the Soviets. After October, I965, the Mitsui and Mitsubishi groups followed suit. (One Japanese newspaper commented at the time that the announcement by the Sumitomo group had been made in violation' of the speed limit.)

\section{B. Conclusion of a Contract}

It is often the case with commodities that are generally influenced by market conditions (iron and steel, textiles, fuels, non-ferrous metals, etc.) that representatives of an' East European trade organization will visit Japan and, after an investigation of the supply-demand situation and the prices of the commodities concerned, will execute a contract in Tokyo. Such contracts are concluded between the Japanese party and the Eastern European party concerned either once or twice a year, depending upon whether the contract covers the demand of a whole year or of only a six-month period. As a result, Japanese business circles are occasionally shocked by a sudden fluctuation in business conditions or prices.

In many cases the terms of a contract are determined beforehand, generally by each public corporation of the Eastern European countries, and the Japanese trader is implicitly required to sign the contract which the East European counterpart 
has prepared without proposing any changes. This is particularly true of contracts involving a party from the Soviet Union. In such cases, the Soviet party often makes an offer, refusing to allow alterations in the terms by the Japanese party.

Negotiations concerning technology-intensive items, such as machinery or plants, are usually conducted by a negotiating team sent by each country to the other. In many cases, however, the contract is actually executed in the capital of the East European party concerned. Technical matters are dealt with first, and commercial matters, such as the terms of credit and prices, are tackled at the last stage of the negotiation.

The final decision to purchase in an East European country is not made by the trade corporation alone; the future user, the competent authorities, and related technology research institutions also play a role. In addition, sometimes the East European' party, not content to deal with a seller from one country, invites the participation of companies from other countries, thus obliging the Japanese seller to make substantial concessions if it is to be ultimately successful.

All Japanese all-around trading companies have set up offices in the capitals of East European countries. (Hungary, alone, does not permit the establishment of a formal resident office.) Such resident offices are desirable from the point of view of Japanese trading companies, in that they provide a site from which to investigate the local market and to acquire other relevant data. In addition, they can make available information on their products to the host country.

Recently Eastern European countries have made adjustments in their laws and regulations on resident offices and commercial activities of the staffs of foreign enterprises, so that foreign enterprises have come to enjoy more favorable treatment as regards equipping of offices, renting houses for their staffs, obtaining long-term visas, and so forth. Among the countries of Eastern' Europe there are some (Rumania and Poland) where a charge, such as a license fee, is levied on the activities of resident staffs of foreign countries. However, there are others where no charge is imposed at all.

Some East European countries have set up corporations which collect commission fees from foreign enterprises as the agents carry out commerical activities in their territory. In these countries, commercial activity of foreign' enterprises is prohibited in principle. It seems, however, that in a case where a foreign enterprise has concluded a representation contract with the government corporation mentioned above, the enterprise is permitted to establish a resident office, and its business activities are tacitly approved. In some East European countries, moreover, the establishment of an office by a foreign enterprise is permitted on condition that the enterprise concerned renders an installing service, after-case service, and other general technical guidance with regard to a plant export.

Before permitting the opening of a resident office by a Japanese trade firm in Moscow, the Ministry of Foreign Trade of the Soviet Union considers the matter in conjunction with the question of increasing the number of the staff in the Soviet 
trade office in Tokyo as well as the question of setting up a trade mission or a branch office of a trade corporation in other Japanese cities. In some instances the Ministry has refused to give official permission for Japanese firms to open resident offices in its capital on the ground that the government of Japan has not yet complied with its demands.

\section{Organizations for Trade Promotion}

There are two categories of organizations which are concerned with trade and economic relations with Eastern Europe. On the one hand are ordinary economic organizations which maintain relations with the Soviet Union and East European countries as part of their activities. On the other hand, there are social organizations set up to promote trade with these countries as their primary object. To the former category belong the Keizai Dantai Rengo-kai, or the Federation of Economic Organizations (Mr. Kogoro Uemura, Chairman); and the Nippon Shoko Kaigisho, or the Japan Chamber of Commerce and Industry (Mr. Shigeo Nagano, Chairman). Each of these two bodies has had its chairman and other members installed in important posts on the Japanese-Soviet Economic Committee, and on other bilateral economic committees which have recently been established by Japan and East European countries. They have assumed the role of secretariats for those committees. In this sense, it can be said that the part the two organizations play in trade relations between Japan and the countries of Eastern Europe is not different from the one they play in trade relations between Japan and regions other than Eastern Europe.

Included in the category of social organizations are the Nippon Kokusai Boeki Sokushin-kai, or the Organization for the Promotion of International Trade of Japan (Mr. Tanzan Ishibashi, Chairman); the NISSO Kyokai, or the Japan-Soviet Union Society (Tetsuhiko Tozawa, Chairman); the Soren Too Boeki-kai, or the Organizaiton for the Trade with the Soviet Union and East Europe (Mr. Shigeo Horie, Chairman); and the NISSO Boeki Kyokai, or the Japanese-Soviet Trade Association (Mr. Katsujiro Nagai, Chairman).

Initially, the Japanese government took a negative stand toward trade with Communist countries, largely due to the Cold War. As compared to trade with other regions, there were simply too many barriers to trade with the East in both the export and import system and the settlement system. These included such things as COCOM restrictions on export, the requirement of advance permission concerning importation from countries with which Japan has no diplomatic relations, the compulsory barter system, and so on. Eventually, however, those Japanese companies engaged in trade with Communist countries realized that it was more effective to act in concert than to depend on individual efforts in their negotiations with the government and with other concerned quarters in their attempt to solve these difficulties. It was through such a realization that trade promotion organizations came to be established. 
Existence of the Japan-Soviet Union Society dates to pre-World War II. Its sphere of activity includes not only the economy and trade, but a wide range of fields, such as culture and education. Similarly, the history of the Organization for the Promotion of the International Trade of Japan, and of the Organization for the Trade with the Soviet Union and East Europe goes back many years. The latter is a successor to NISSO Too-Boeki-kai, or the Organization for the Trade between Japan and the Soviet Union and East Europe, founded in 1957. It was reorganized in 1966 and given its present name. These latter two organizations conducted propaganda for consummation of inter-governmental trade agreements with the respective countries of Eastern Europe to replace agreements made by private groups with trading organizations there. Their other activities included maintenance of communication and coordination of action between Japanese and Soviet authorities, mediation and good offices in business transactions, receiving and sending of economic and technical missions, holding of trade fairs and economic conferences, and conducting scientific research.

As trade and economic relations with the East European countries developed and the Japanese business circles entered into the East-West trade in earnest in the latter half of the I960's, members of some trade promotion organizations began to experience doubts as regards the raison d'être of their organizations as trade promotion bodies. In the Organization for the Trade between Japan and the Soviet Union and East Europe, a move began to abandon the position of criticism toward the government and to establish a working relationship with it. After its reorganization in 1966, it came under the control of Keianren, and in 1971 it was licensed by the Ministry of International Trade and Industry as a corporate juridical person. Since 1972, it has received government subsidies for its activities in organizing trade fairs and promoting technical cooperation and research activities. Furthermore, the Organization for the Promotion of International Trade has lost its contacts with the Soviet Union. In February, 1967 , it signed a new protocol on JapanChina Friendship Trade with the Trade Promotion Association of China. In April of that year, the State Science and Technology Commission and the National Chamber of Commerce of the Soviet Union severed relations with the Organization, on the ground that portions of the protocol were libelous to the U.S.S.R. Since then, the Organization has been primarily concerned with promoting trade with China and Albania.

\section{III}

\section{Scientific and Temohital Cooperation}

The government of Japan has often been asked by the East European countries to conclude scientific and technical cooperation agreements on an inter-governmental basis. For instance, the Minister for Foreign Trade of Czechoslovakia, Mr. Vales, and the Vice-Chairman of the State Science and Technology Commission of the Soviet Union, Mr. Gvishiani, on the occasion of their visits to Japan in I968 and 
I969 respectively, proposed to the Japanese government that it conclude an agreement of scientific and technical cooperation with their governments. However, the Japanese government did not respond to such proposals on the ground that it had never before concluded such a comprehensive agreement. It felt that there was no point in the government's concluding such agreements with the Communist bloc, since individual private enterprises, not the government, engaged in such scientific and technical exchanges.

Private organizations of Japan have concluded scientific and technical agreements with the Science and Technology Commission of the Soviet Union. Such an agreement was concluded by the Mitsui group in I966. It placed particular emphasis on the chemical industry. The Organization for the Trade with the Soviet Union and East Europe made a similar agreement in 1967 . Recently, a number of all-around trading companies have also concluded such agreements with the Soviet Union. Moreover, the Organization for the Trade with the Soviet Union and East Europe has concluded agreements with Hungary, Bulgaria, Yugoslavia, and Rumania, which are aimed primarily at receiving and sending various expert teams, holding lectures and symposiums, and similar activities.

While scientific and technical cooperation is not directly related to usual export and import transactions, it is recognized as an important means of access to East European markets, which tend to be exclusive. Through scientific and technical cooperation it becomes possible to have contact with ministries, research institutions, and other groups which are behind the trade organizations of Eastern Europe and which are otherwise difficult to approach. Contacts of this type provide an opportunity to perceive the trend of the demand in the East European countries.

But not all Japanese enterprises were eager to conclude such agreements. Some assumed a negative attitude toward scientific and technical exchange with the countries of Eastern Europe for fear that such an exchange might end in a unilateral flowing out of their technology. Others were afraid that the safeguards for technical knowhow provided in those countries might prove insufficient. This attitude was reflected in the policy of the Japanese government. However, on the occasion of the meeting of the Foreign Ministers of Japan and the Soviet Union in January, r97I, it was agreed that talks would be held between the two governments for the conclusion of an agreement, and it is expected that an inter-governmental agreement on scientific and technical exchange will be concluded in the future.

\section{IV}

\section{Refinement of the Trading Relationships}

\section{A. Joint Economic Committees}

Since Ig66, bilateral joint economic committees have been established between Eastern and Western countries for the regulation and promotion of their trade and economic relations. The Japan-Soviet Union Joint Economic Committee has already 
been founded, and similar committees have recently been set up between Japan and East European countries as well. All such committees are based on the pattern that each of two countries establishes an economic sphere, with the committees of both countries holding a joint meeting once a year.

\section{The Japan-Soviet Union Joint Economic Committee}

In I965, the memorandum for the establishment of the Joint Economic Committee was signed by Japan and the Soviet Union. Under the memorandum, leaders of the economic circles in both Japan and the Soviet Union were to meet once a year to consult on various problems relating to the promotion of economic exchanges, such as trade and technical cooperation, between the two countries. Since the first meeting in I966, a meeting of the Joint Committee has been held every year. Consideration of, and negotiation on, concrete projects related to cooperation for the development of Siberia have been important aspects of its work. (For an organizational chart of the Committee, see Appendix A.)

\section{The Japanese-Polish Mixed Economic Committee}

This committee was established in Ig67 as an inter-governmental mixed committee, but representatives of private enterprises have also participated in an advisory capacity. The Committee, desirous of further development of trade and economic relations between' Japan and Poland, holds consultations annually for the purpose of (I) expanding trade in traditional items and discovering new items, (2) considering the possibility of industrial collaboration, (3) considering the possibility of scientific and technical cooperation, and so forth.

\section{The Joint Meeting of the Japanese-East German Economic Committees}

When the economic mission of East Germany visited Japan at the beginning of I97I, a meeting was held between the leader of the mission, Vice-Minister for Economic Affairs, Mr. Beil, and top leaders of the Japanese industrial circles, and it was agreed between them to set up a standing private economic committee in each country. Accordingly, the Japan-GDR Economic Committee was established in East Germany with Mr. Lange, President of the Steel and Metal Trade Corporation, as its chairman. In Japan a committee of the same name was established. The two Committees have already held a joint meeting.

\section{The Japan-Hungary Round-Table Conference}

In I97r, the Japan Club was brought into being within the Chamber of Commerce of Hungary, with the participation of major enterprises in Hungary. Correspondingly, the Japan-Hungary Economic Club (Chairman, Mr. Sinzo Oya, President of the Teijin Co., Ltd.) was organized in Japan to promote trade between Japan and Hungary. In November, I97I, the first Japan-Hungary Round-Table Conference was held by the two clubs in Budapest. 


\section{Additional Committees}

Besides the joint meetings mentioned above, various economic committees have recently been established in Japan. These committees are making preparations to hold meetings in the near future on the establishment of similar bodies in counterpart countries.

(I) The Japanese-Bulgarian Economic Committee, established in April, I972. The Chairman of the Japanese side is Mr. Hiroki Imazato, President of the Nihon Seiko Co., Ltd. The Chairman for the Bulgarian side is Mr. Papazov, Chairman of the Committee on Higher Education in Science and Technology.

(2) The Japanese-Czechoslovak Economic Committee, established in May, 1972. The Chairman of the Japanese side is Mr. Hideo Shinojima, President of the Mitsubishi Kasei Co, Ltd. The Chairman of the Czechoslovakian side is not yet designated.

(3) The Japanese-Rumanian Economic Committee, established in May, I972. The Chairman of the Japanese side is Mr. Hitoshi Isano, President of the Kawasaki Heavy Industries Co., Ltd. The Chairman of the Rumanian side is not yet designated.

(4) The Japanese-Polish Economic Committee, established in June, I972. The Chairman of the Japanese side is Mr. Toshio Doko, President of the Tokyo Shibaura Electric Co., Ltd.

(5) The Japanese-Yugloslav Economic Committee, established in June, rg72. The Chairman of the Japanese side is Mr. Kizo Yasui, Chairman of the Toray Co., Ltd.

\section{B. Expansion of the Governmental Role}

In drawing up the Eighth Five-Year Plan, covering the period $1966-70$, the Soviet Union held talks with West European capitalist countries as a result of which both bilateral trade agreements and scientific and technical cooperation agreements were concluded. Those inter-governmental agreements came to play a very important role in guiding, as well as guaranteeing the performance of, the activities of individual enterprises of both parties.

In Japan, however, the primary emphasis has been on encouraging and promoting economic activities by private enterprises, on the basis of a free economic system. The role of the government in the operation of the economy has, therefore, naturally been limited in its scope. Influenced by the government's post-war foreign policy of cooperating with the United States, the private initiative has tended to play a particularly important role in promoting trade with Eastern Europe, compared with trade with other regions. Accordingly, direct participation of the Japanese government in the trade and economic relations with East European countries has been confined to conducting annual negotiations with the Soviet Union on the basis 
of the trade agreement, and with East European countries on the basis of the agreement on the mixed committee with Poland.

The Minister for Foreign Trade of the Soviet Union, Mr. Patolichev, who visited Japan in September, I97I, to sign the Second Long-Term Trade Agreement, requested in his talks with leaders of the government that Japan participate vigorously in cooperative projects for the development of Siberia. His request emphasized the need to insure fruition of these large-scale Siberian projects.

With regard to these cooperative Siberian development projects, emphasis has been placed on the development of energy resources in recent years. The investment expected from Japan for the projects has amounted to between $\$ 500$ million and $\$ \mathrm{I}$ billion. Such large sums take the matter out of a purely private domain, and make an assessment of national priorities necessary. They also take the matter out of the economic field to a certain extent and place it in the realm of international politics.

Japanese industry is also hoping for a high level of government interest and participation in the development of Siberia. This is important, as a practical matter, because the scope of governmental intervention has become more significant in such matters as approval of credits from the Export-Import Bank, export on a deferred payment basis, and so on. It can be pointed out, moreover, that expectations of government participation have also resulted inevitably from the growing need to strengthen the negotiating power of the Japanese enterprises to obtain favorable results when dealing with the powerful state-owned trade organizations of the East European countries, as the scope of the projects becomes monumental.

\section{Channeling Trade Operations}

It is characteristic of socialist states that foreign trade is incorporated in the economic plan as a component part. In addition, the administrative agencies of trade are commodity-wide, state-owned corporations, and the power to conduct trade transactions is concentrated in the hands of such corporations. In Japan, on the other hand, a number of enterprises compete vigorously for orders from abroad. This permits the trade corporations of the East European countries, through which their foreign trade is channeled, to take advantage of the excessive competition on the Japanese side. The result is that the terms of trade shift unfavorably for Japan in many cases. Notable examples of such a tendency may be found in the trade dealings between Japan and the Soviet Union.

Soviet authorities assume a strong negative attitude toward the suggestion of Japanese industry that it channel its trade with the Soviet Union. They maintain that it is a natural consequence of the socialist system that the state-owned trade organizations monopolize foreign trade and, backed by the authority of the state, give full play to their peculiar strength. But they insist that this does not suggest, by any means, adoption of a discriminatory policy toward any foreign country. However, according to the logic of the Soviet authorities, it is improperly discriminatory for Japanese enterprises to coordinate relations within an industry in order to 
strengthen their negotiating power in dealing with the National Trade Corporations of the Soviet Union so as to avoid disadvantageous transaction terms which could be imposed upon the Japanese through the "divide and rule" tactics of normal competition. Furthermore, if the coordination is directed solely toward the Soviet Union, it constitutes a challenge to the socialist system itself. This attitude seems rather odd, based on the reaction of the Soviet Union in the past to cartel activities of the Japanese industry in its overseas business. The Soviet Union is apparently not opposed to all such activities. It seems to take issue only with cartels avowedly established to deal with it.

\section{V}

\section{Frnancing Trade Arrangements}

\section{A. Method of Settlement}

There are two forms of settling accounts-settlement in cash, and settlement on a letter of credit. In most cases, Eastern European countries demand settlement on the letter of credit method for their exports and settlement in cash, after receipt of documents, for their imports. Some believe that they settle in cash for their imports because payment by their trade organizations is considered reliable. Others believe, however, that the cash settlement method is used for imports because the countries of Eastern Europe want to avoid the necessity of having their state-operated trade organizations bear bank charges for opening letters of credit.

Under the provisions of the trade agreements between Japan and the East European countries, trade transactions are to be settled in convertible currencies. At present the United States dollar is used as the settlement currency in all transactions between Japan and the East European countries. However, since Ig68, when the international monetary unrest started, the trade organizations of some countries, including the Soviet Union and Poland, have resorted to the policy of including either a gold clause or a re-negotiation clause in a contract for the export of goods of their countries. The gold clause provides that if there is a change in the gold par value of the currency to be used in settlement under the contract, the price of exports should be raised or lowered in proportion to such change. The re-negotiation clause provides for holding a consultation on the price of exports in consideration of the new gold par value of the settlement currency after a change in the exchange rate. Japan's exchange control law requires approval by the government before an importation contract with such clauses can be executed. The government, for its part, has not given approval to such a contract because it supports the IMF system and because the socialist countries demand insertion of such a clause in order to avoid risks only where their exports are concerned.

At the fifth meeting of the Japanese-Soviet Joint Economic Committee held in Tokyo in February, I972, the Japanese members proposed a method of direct settlement in yen and ruble with a view to avoiding a loss resulting from a fluctuation of 
exchange rates. The basic idea of the proposed system, which has been developed, by analogy, from the system of settlement in yen and yuan recently adopted between Japan and China, is to set the exchange rate between yen and ruble by an agreement between both parties for a fixed period of from three to six months. Each party could open an account with a bank in the other country, using the currency of that country. Payments for importation would be made from that account. The balances in the accounts of both parties would be cleared at the end of the fixed period.

Thus far in Japanese-Soviet trade, an excess of imports over exports has been recorded on the Japanese side. Consequently, as Japan has always had a negative balance of payments with the Soviet Union, adoption of the method of settlement in yen and ruble would result in an increase in the Soviet yen' account in a bank in Japan. This method has been considered to be convenient for Japan. Recently, however, the balance of the Japan-Soviet Union trade has turned in Japan's favor, and the adoption of the above system would result in an increase in the ruble balance. This method of direct settlement in yen and ruble is presently being carefully considered in Japanese trade circles, and a conclusion will be reached before long.

\section{B. Long-Term Credit}

The pressure for credits to finance East European trade has now somewhat declined. Japan has made an attempt to cooperate in international efforts to harmonize the granting of credits to East European countries. It joined the Berne Union in 1970, and participated in the Working Group on Export Credit of OECD. Japan's policy in giving credits, moreover, has been based on the matching principle, which involves giving a credit on the same conditions as those given by other countries.

The method for giving credits adopted in Japan is in the form of a supplier's credit, that is, providing financing for the exporter. A buyer's credit, such as a bank loan to assist payment on the importer side, is n'ot given. As for the period of credit, it varies depending on the amount of the credit, but generally it extends to between five and eight years from the shipment of the cargo.

Japan does not give bank loans to the East European countries for a number of reasons. Japanese exporters are trading firms, and excessive competition is prevalent among them. Thus, a payment ability in' the buyer would unduly increase that party's capacity to exploit the competition among Japanese firms and, hence, to secure orders on terms less than favorable for the Japanese. Also, the interest rate on loans to East European countries has been kept low at the expense of the exporter-the lender-who has used part of his gross profit to bear the cost. Since it would be difficult to amend the low interest rate upwards, it is not possible for the lending bank to profit from a bank loan. Furthermore, a compensation given to the bank by the exporter from his exportation profit, on the basis of a consortium organized by the bank and the exporter, is regarded as a donation within the framework of the tax law of Japan.

There is a clear reason why the East European countries are anxious to secure 
bank loans. Unless the buyer secures a means of payment beforehand, the exporter, with whom the buyer has entered into an import contract, might not be able to obtain a credit from the Export-Import Bank. Also, without such means of payment, the government of the exporter might not permit the contract. If the contract is denied permission by the government of the other party, the trade organization which made the contract might even be regarded as causing an obstacle to the implementation of the economic plan. For these reasons, the government of Japan plans to undertake a re-evaluation of its position' on extension of bank loans to East European countries in the near future.

Appendix A

The Organization of the Japan-Soviet Union Joint Economic Committee

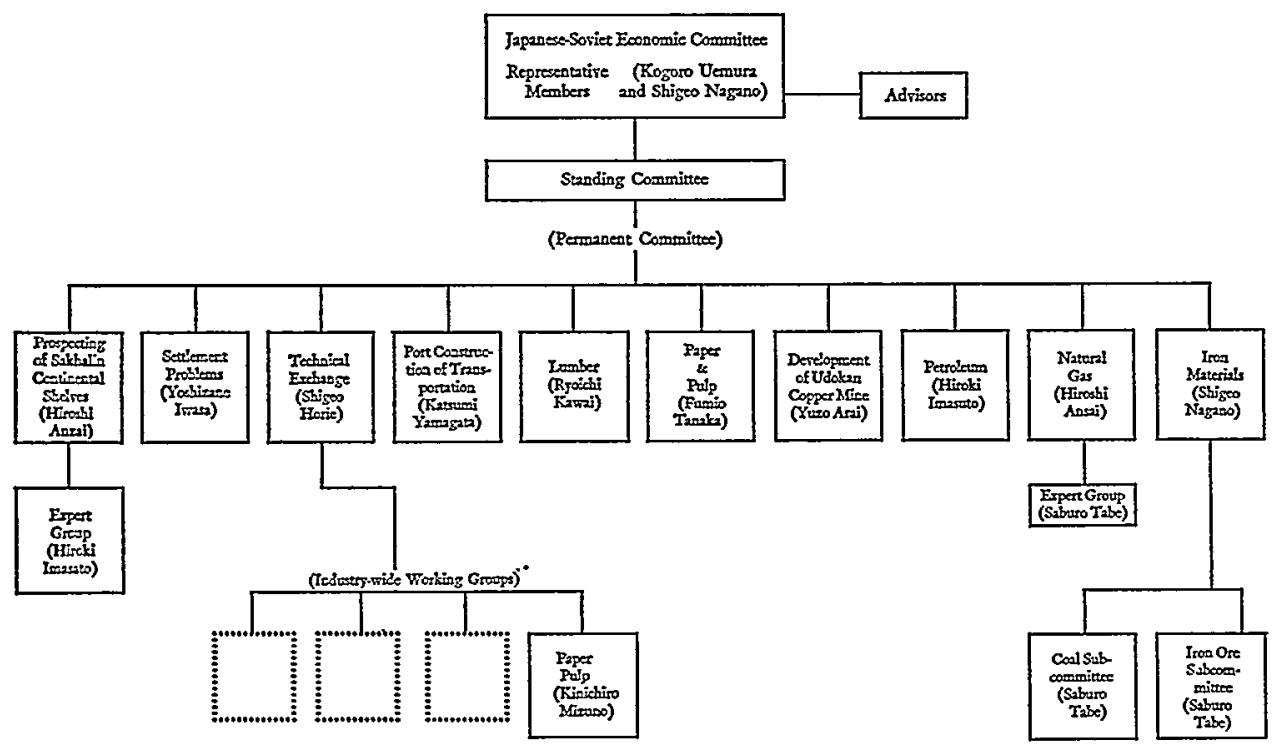

Appendix B

The following is a list of delegations which the Organization for the Trade with the Soviet Union and the State Science and Technology Commission of the Soviet Union have already agreed to exchange:

A. Soviet Delegations visiting Japan (according to specialization) I967

(I) Turbo-genierators

(2) Commodity inspection

(3) Electrical construction works 
I968

(I) Large-scale shipbuilding

(2) Construction of large dams

(3) Rice milling facilities

(4) Public works (construction of factories)

(5) High-pressure boilers

I 969

(I) Construction of metallurgical factories and mining enterprises

(2) Integrated mass-production of pianos

(3) Instruments recording vibrations of building foundations during severe earthquakes

(4) Cooperation for the production of scientific instruments

I970

(I) Production of synthetic sewing threads and surgical threads

(2) Production of trucks

(3) Production of chemical machinery

(4) Facilities for the production of luminiferous materials

I97I

(I) Welding

(2) Telecommunications

(3) Steel

(4) Industrial robots

(5) Mammoth tankers

B. Japanese Delegations visiting the Soviet Union

I967

(I) Commodity inspection

(2) Machine tools

(3) Toy industry

(4) Turbo-generators

I968

(I) Electrical construction

I969

(I) Ultra-high-pressure power transmission

I970

(I) Inspection of construction and operation of boiler machinery

(2) Questions of improving productivity

(3) Inspection of the production and operation of telecommunication systems 


\section{I97I}

(x) Oil hydraulic industry

(2) Visit to the Soviet Union of the students of the Trade College

(3) Exploration of Siberia and the Far East

(4) Large dams

(5) Safety engineering

(6) Machine tools 